Early Theatre 10.2 (2007)

LEANNE GROENEVELD

\title{
A Theatrical Miracle: The Boxley Rood of Grace as Puppet
}

In 1538, during the early days of the reformation in England, a miraculous crucifix owned and displayed by the monks of Boxley Abbey, located near the town of Maidstone in Kent, was examined by a commissioner of the English church and declared to be a fraud. A number of accounts, most secondhand, of the 'discovery' and destruction of this allegedly fraudulent miraculous crucifix survive. In these accounts, descriptions of the Rood's powers range from the simple - the ability to move its eyes and to open and shut its mouth - to the elaborate and fantastical — the ability to weep, to bite its lip, to frown, to smile, to foam at the mouth, to nod its head, to bow itself down, to lift itself up, and (it is implied) to perform sexual acts. Every account takes for granted that these movements were effected by a human operator and further that this operator was concealed from the many pilgrims who flocked to the abbey because they assumed naïvely, even ignorantly, that the Rood's movements were effected by God.

In his recent study Magic on the Early English Stage, Philip Butterworth introduces his chapter on mechanical images, automata, puppets, and motions - of which he offers the Boxley Rood as example—by describing what he considers to be the two possible functions of these devices and the two possible objectives of the agents who manipulated them or set them in motion. It appears that Butterworth is concerned to establish clear categories: he begins by distinguishing the puppet from the automaton and ends by distinguishing the theatrical and representative from the magical and deceptive:

Mechanical means [of movement of an image] may be said to fall into two categories: one, in which the movement is started and left to run its course, i.e. some form of clockwork arrangement, and secondly, mechanical means through continued attention of an operator. These two modes are capable of variation of function and purpose. Similarly, the function of the operator may also be conditioned by purpose. Is the operator seen or unseen in such manipulation? Do the witnesses 
of such movement recognize the terms of reference by which movement occurs? If the answer to this question is 'Yes' then the skill of the operator and the created action may be enjoyed and appreciated in relation to the movement. If the answer is 'No' then some form of deception, illusion or pretence is likely. This distinction lies at the centre of notions of theatre and its acceptance is one with which the performance of magic is in constant negotiation. ${ }^{1}$

Butterworth here accepts and adopts a familiar dichotomy, that of theatre and magic; presumably all instances of mechanical movement, of images, automata, and puppets, fall into one or the other of these distinct and opposed categories. Later in the same chapter he discusses the Rood of Boxley as an instance of the latter:

The Rood of Grace at the Abbey of Boxley in Kent was, according to William Warham, Archbishop of Canterbury in 1524, 'much sought from all parts of the realm' primarily because the Abbey was 'so holy a place where so many miracles be shewed'. The Rood of Grace was the apparent source of these 'miracles' and consisted of a cross bearing an image of the crucified Christ that was capable of moving. The notoriety of the image arose from the apparent deception through mechanical means by the monks upon the viewers. ${ }^{2}$

In Butterworth's opinion the reputation of the crucifix as miraculous suggests deception, and since deception precludes theatrical representation, the Boxley Rood cannot be considered a theatrical object (which in the case of an image moved 'through continued attention of an operator' might be classified a puppet $\left.{ }^{3}\right)$. The distinction depends entirely upon the recognition by the audience of the agent responsible for, and not the mechanics behind or nature of, the effected movement:

Although the Rood of Grace at Boxley can not be considered as puppetry, the techniques by which parts of the figure of Christ were manipulated are not dissimilar from some of those used in puppetry. Identification and revelation of the deception in purpose and communication by the Rood of Grace prevents it from being considered as puppetry. Even though puppeteers may be seen or unseen in performance, the tacit acknowledgement of their existence is critical to understanding of the agreement between puppeteer and audience. The anger reported in ... letters [describing the Rood of Boxley as mechanical fraud], when deception was discovered, is similar to that experienced by an audience when an actor, pup- 
peteer or conjuror (modern sense) breaks the unspoken understanding concerning the nature of pretence. Under these conditions an audience feels betrayed and cheated. ${ }^{4}$

Butterworth's reading of the Rood as magic trick and therefore fraud goes against most current representations of the Boxley crucifix, agreeing instead with (protestant) representations to the latter half of the nineteenth century. Historians tended to accept as given the crucifix as magical deception until articles by J. Brownbill $(1883)^{5}$ and T.E. Bridgett $(1888)^{6}$ succeeded largely in re-categorizing the crucifix as theatrical representation, not feigned miracle, a reading supported by such recent critics as Clifford Davidson, Margaret Aston, and (to an extent) Peter Marshall. ${ }^{7}$

Bridgett (Marshall maintains 'somewhat tendentiously' ${ }^{8}$ ) identifies the historical problem of the Boxley Rood as a problem of determining right reading (and of identifying right readers). Working with the same categories of movable image as Butterworth, he protests that 'Englishmen before the Reformation were not the idiots that some would seem to suppose. ${ }^{9}$ They were not gullible and would have been well aware that the Rood of Boxley's movements were effected by internal devices and an external operator and therefore that the object was merely representative, not miraculous. Reformers and historians saw deception where it never occurred, for suspect and self-interested reasons. 'Protestant literature', Bridgett writes, 'from the time of the Reformation to the present day, is filled with this assumption of the ignorance, folly, and superstition or knavery of Catholics, and the enlightenment and honesty of whatever is sectarian'. ${ }^{10}$ In the end either those who argue that the Rood was theatrical or those who argue the Rood was magical must be wrong. 'It is a choice of difficulties', Bridgett writes. 'Either Catholics had been gulled or Protestants have been bamboozled (one must be pardoned the words, there are no others)'. ${ }^{11}$

Bridgett suspected the latter, as do most critics today, while Butterworth suspects the former. But it may be that neither is unproblematically the case. Perhaps another way to approach the problem is to question the exclusivity of the categories of theatre or representation and magic or miracle, at least within the late medieval popular religious aesthetic, and to wonder again what it might have meant to read 'miraculous' images correctly. It may be that the Boxley Rood straddled categories in a manner unacceptable to protestant reformers, who in response emphasized and exaggerated the theatricality of the image, in their representations transforming it into the puppet that 
Butterworth insists it was not originally, assuming for themselves the role of puppeteer. In this way protestant writers exploited evolving popular constructions of and associations with the puppet in general and the marionette in particular, as devices that appealed only to the naïve, ignorant, and, peculiarly, the sexually licentious. They also enforced clearer categories of function and purpose for images, categories taken for granted still today.

\section{Evolution of the Rood: the accounts}

In a circa 1538 letter to Lord Cromwell, Geoffrey Chamber, the commissioner charged with (as he describes it) the 'defacyng of the late Monasterye of Boxley, and pluckyng down of the Images of the same', ${ }^{12}$ describes probably most accurately both the image's repertory of movements and the mechanisms that produced them. Chamber writes:

I founde in the Image of the Roode callede the Roode of Grace, the whiche heretofore hath beene hadd in greate veneracion of people, certen ingynes and olde wyer, wyth olde roton stykkes in the backe of the same, that dyd cause the eyes of the same to move and stere in the hede thereof lyke unto a lyvelye thyng; and also the nether lippe in lyke wise to move as thoughe itt shulde speke. ${ }^{13}$

In Chamber's report the Rood of Boxley is credited only with being able to move its eyes and its lower lip to simulate speech. Charles Wriothesley, a probable eye-witness to the image's later unmasking and destruction at Paul's Cross, corroborates Chamber's account in his Chronicle of England during the Reigns of the Tudors, explaining that the crucifix 'was made to move the eyes and lipps by stringes of haire, when they [the monks of Boxley] would shewe a miracle'. ${ }^{14}$

Another likely eyewitness to the dismembering of the Rood was the author of the anonymous London Chronicle during the Reigns of Henry the Seventh and Henry the Eighth, a journal or diary that discontinues in the year 1545, presumably with the death of the chronicler. He writes:

On saynt Mathies day th'apostulle the xxiiij day of February Sonday did the bisshop of Rochestere preche at Polles cros, and had standyng a fore hym alle his sermon tyme the pictur of the Roode of grace in Kent that had byn many yeris in the Abbey of Boxley in Kent, and was gretely sought with pilgryms, and when he had made an ende of his sermon the pictor was toorn alle to peces. ${ }^{15}$ 
'Picture' here suggests merely a 'three-dimensional representation of something, esp. as a work of art; a statue, a sculpture' (OED). This account oddly does not mention sticks, engines, strings of hair, or the motions they supposedly—and eventually infamously_effected.

In an undated letter written (probably in 1538) by John Finch, an English reformer living abroad, the Rood is credited with slightly more impressive powers. Finch reports as 'a certain fact' that

By means of some person pulling a cord, most artfully contrived and ingeniously inserted at the back, the image rolled about its eyes just like a living creature; and on the pulling of other cords it gave a nod of assent or dissent according to the occasion .... Then again, by some other contrivance unknown to me, it opened and shut its mouth. ${ }^{16}$

Nicholas Partridge reports in a roughly contemporary letter sent from Frankfurt to Henry Bullinger that the infamous Rood 'turned its head about, rolled its eyes, foamed at the mouth, and poured forth tears down its cheeks' ${ }^{17}$ In yet another letter written by reformer John Hoker, the Rood is attributed with still other life-like movements. The Latin text of the letter is printed in Gilbert Burnet's History of the Reformation of the Church of England; ${ }^{18}$ Bridgett in his article quotes from George Cornelius Gorham's 'literal translation' 19 in Reformation Gleanings (more about this translation later): ${ }^{20}$ 'There was lately discovered a wooden god of the Kentish folk, a hanging Christ, who might have vied with Proteus himself. For he was able most cunningly to nod with his head, to scowl with his eyes, to wag his beard, to curve his body, to reject and to receive the prayers of pilgrims'. ${ }^{21}$

In 1539 reference was made to the Boxley Rood in the 'Declaration of the Faith', a treatise composed by members of Cromwell's circle that, according to Peter Marshall, 'seems to have been intended for overseas consumption, with the purpose of portraying Henry as a reforming yet unquestionably orthodox ruler against whom no Catholic "crusade" could conceivably be justified'. ${ }^{22}$ In this document, Boxley and other roods are described again as capable of moving their eyes and lips and their bodies, though the exact nature of the movements of the latter are not specified: 'At Boxlegh and sundry other places, monkes and frieres had devised prestigious ymages of Crist crucified ... by engins, visses, and crafty conveyances tornyng their eeis, moving their lippes and stirring them selfes when certain keys and stringes ... were bent or pulled'. 23 
In The Pilgrim: A Dialogue on the Life and Actions of King Henry the Eighth, William Thomas described a conversation he allegedly had in 1547 'After supper on an evening, sitting by the fire in company of seven or eight gentlemen in a rich merchant's house in Bonony'. ${ }^{24}$ Over the course of this conversation, he was forced to make a defence of the recently deceased king, including the iconoclasm of his government. Thomas's strategy was not to attack the use of images generally; he was after all a stranger alone in a Catholic state. Instead he set out to discredit English images specifically and in his text makes a strange, sweeping claim: that almost all English roods and 'Ladies' were capable of movement, through the deceptions and deceits primarily of the spiritual religious. Yet he distinguishes one image particularly from all the rest, a crucifix Bridgett believed was the Rood of Boxley.

For as you have here our Lady in so many places ... even so had we our Lady of Walsingham, of Penrice, of Islington, St. Thomas, St. John of Salstone that conjured the devil into a book, and so many holy roods that it was a wonder. And here and there ran all the world; yea, the King himself, till God opened his eyes, was as blind and obstinate as the rest. I mean in the time when he wrote against Martin Luther. And those roods and these our Ladies were all of another sort than these your saints be; for there were few of them but that with engines that were in them could beckon, either with their heads and hands, or move their eyes, or manage some part of their bodies, to the purpose that the friars and priests would use them; and especially one Christ Italianate, that with the head answered yea and nay at all demands. ${ }^{25}$

'No doubt he [Thomas] was referring to the Rood of Boxley', Bridgett concluded; 'why called Italianate I do not know'. ${ }^{26}$ Whether or not the 'Christ Italianate' that nodded and shook its head in answer to questions was the Boxley Rood probably cannot be determined, but the use of the adjective may be significant, as will be discussed later.

In 'The Fantasie of Idolatrie', a ballad published in 1563 in John Foxe's Acts and Monuments, Cromwell's propagandist William Grey attributed the Rood of Boxley with simple, obviously counterfeit, and crude movements in public (to emphasize the credulity of the Boxley pilgrims) and lifelike movements, even human motivations and desires, when out of the public gaze. The account is satiric yet extremely disturbing: James Gairdner in Lollardy and the Reformation in England refused to quote from certain sections of the ballad, which he insisted contained 'indecencies': ${ }^{27}$ 
He was made to Iogle

His eyes would gogle

He wold bend his browes \& frowne,

With his head he would nod

Lyke a proper yong God

His chaftes would go vp $\&$ downe.

The saying was

That this rode of grace

And our Lady of Walsyngham

Should haue bene maried

Sauyng they taried

To spie a tyme howe and whan.

For sometime in the nyght

If the people say ryght

As ij. louers eche other loue to procure

They did mete very oft

Wherby it was thought

That our Lady and he had bene sure. ${ }^{28}$

In his 1565 Answer to John Martiall's Treatise of the Cross, James Calfhill demonstrates that he was familiar with Grey's ballad, or at least with the popular representations of the Rood that inspired it. His text presents the image at Boxley as unremarkable, even common-place, even as it (again tonguein-cheek) accepts the humorous notion of the Rood's secret life:

For they ['our Parish-Priests and popish Chaplains'] have made Roods with rolling eyes and sweating brows, with speaking mouth and walking feet. I report me to the Rood of Grace, the Rood of Winchester, the very Cross of Ludlow, and Jack Knacker of Witney. Nor marvel if the Cross be so deep in your books, that can stand a high-lone, and walk on the Altar; that can run in the night-time from $S$. John's chapel into our Lady's, and will not for jealousy abide from her. ${ }^{29}$

By 1570, more than thirty years after the Rood's destruction, its reported mechanical wonders had become still more spectacular. In his Perambulation of Kent William Lambarde provides a description of the image's abilities embedded in an extended account of its creation by a 'cunning Carpenter of our countrey' taken hostage during hostilities with France. ${ }^{30}$ In an attempt to raise money for his ransom, the carpenter 
thought it best to attempt some curious enterprise, within the compasse of his owne Art and skill, to make him selfe some money withall: And therefore, getting together fit matter for his purpose, he compacted of wood wyer, paste, and paper, a Roode of suche exquisite arte, and workmanship, that it not onely matched in comelynesse, and due proportion of the partes, the beste of the common sorte: but in straunge motion, varietie of gesture, and nimblenesse of ioyntes, passed all other that before had beene seene: the same being able to bowe downe, and lift up it selfe, to shake and stirre the handes and feete, to nod the heade, to rolle the eyes, to wagge the chappes, to bende the browes, and finally, to represent to the eye, bothe the proper motion of eche member of the bodye, and also a liuely, expresse, and significant shewe of a well contented, or displeased mynde, byting the lippe, and gathering a frowning, frowarde, and disdainefull face, when it woulde pretende offence: and shewing a most mylde, amyable, and smyling cheare and countenaunce, when it woulde seeme to be well pleased. ${ }^{31}$

\section{The Rood as Theatrical: comparison to the player and the puppet}

The above accounts are provided in chronological order to demonstrate more than the simple point (made by many others) that the Rood's movements as represented became more elaborate and exaggerated over time. Descriptions of the Rood seem to have evolved and changed apparently (from the little evidence that has survived) as the English public became familiar with new types of puppets from the continent, capable of more elaborate and life-like movements.

The earliest extant accounts suggest that the Boxley image of Christ was capable only of rolling its eyes, opening its mouth, and perhaps nodding or shaking its head. These movements, according to Reginald Pecock's midfifteenth-century Repressor of Over Much Blaming of the Clergy, were the kinds of movements pilgrims might expect from wonder-working images that had been blessed by God:

it is not inconuenient but it is conuenient ynow3 that God at sumwhile make thilk ymage swete, and that the ymage be moued from oon place into an other place with oute mannys labour, and that the izen of the ymage be turned hidirward and thidirward, and that the ymage semyngli speke, that is to seie, that speche and soun be mad in the ymage bi an aungel of God, as it was doon in the asse of Balaam. $^{32}$ 
The ability to roll the eyes was, according to George Speaight, historian of the English puppet theatre, a characteristic of simple English glove puppets by at least the early seventeenth century. Speaight writes:

These puppets may have been roughly carved figures for the most part, but they were capable of at least one effect that is seldom achieved even to-day: like the Roman marionettes described by Apuleius, they rolled their eyes. In 1609 Ben Jonson referred to 'the French puppets with the eyes turned with a wire', and a Notts villager, lamenting the inability of his neighbours to present a puppet show, complained that 'they'll be out in turning up the white of the eyes'. ${ }^{33}$

Butterworth, discussing the simplest movements attributed to the Rood of Boxley, notes that 'Individual wires through tubes could fulfil single tasks such as: causing the "eyes to move and stir in the head" by lifting or dropping the pupils, or operating the "nether lip" up or down (rather like the articulation of the jaw of the ventriloquist's doll)'. ${ }^{34}$

The more elaborate movements attributed to the Rood by contemporaries are contained either in second-hand accounts or, in one case, in an overtly fictional and figurative representation. Written in Frankfurt, the letters of John Finch and Nicholas Partridge report, and perhaps build on, what itself appears to be the hearsay account of a German merchant. The other contemporary (1538) account cited above, John Hoker's letter to Bullinger, appears in contrast potentially to offer a first-hand account, but its representation of the Rood is unabashedly figurative. ${ }^{35}$ Hoker develops throughout his text a careful and complicated metaphor of the image as actor. His obviously fictional account provides little factual information about the Rood's repertory of movements:

Being laid open he afforded a sportive sight, first of all to my Maidstonians, exhibiting himself from a lofty platform to a crowded throng, some laughing heartily, some almost as mad as Ajax. The stroller was taken hence to London. He paid a visit to the Royal Court. This new guest salutes the king himself after a novel fashion. Courtiers, barons, dukes, marquises, earls swarm round him like bees. They come from a distance, stand around, stare and look him through and through. He acts, scowls with his eyes, turns his face away, distorts his nostrils, casts down his head, sets up a hump-back, assents and dissents. They stare, they deride, they wonder, the theatre rings with their voices, the shout flies into the sky. ... Here again he opens himself, here again the player acts the part skillfully. ${ }^{36}$ 
Hoker never compares the Rood to a puppet, only (it seems) to a human actor. He never uses the Latin 'pupa' to describe the image. Yet in his translation, Gorham uses the term 'puppet' to refer to the Rood: 'They [the crowd or audience] wonder, they are indignant, they stare, they are ashamed to find they have been so deluded by a puppet'. ${ }^{37}$ The original reads as follows: 'Mirantur, indignantur, stupent. Pudet ab idolo tam turpitur fuisse delusos'. ${ }^{38}$ Gorham in his translation anticipates the construction of the Rood as puppet in subsequent popular representations, and specifically as a marionette: a puppet capable of more than goggling its eyes. Only the marionette and not the glove puppet can be described as a 'circulator', an image that actually 'strolls', or is capable of any of the other movements attributed to the image in later accounts: the Christ figure bending its body down and lifting itself back up, moving its joints nimbly, shaking and stirring its hands and feet, nodding its head, gesturing with its hands or head, and climbing down from the cross for clandestine meetings with a lover.

According to Speaight, despite the fact that 'references to puppets in medieval England are scarce and doubtful ... there is sufficient authority for us to believe that both glove puppets and marionettes, used in a fully dramatic manner, were familiar forms of popular entertainment by the fifteenth century'. ${ }^{39}$ And yet he cautions that while 'Marionettes may have been known ... the typical English puppet of the age of Shakespeare [and presumably before] seems to have been a glove puppet'. ${ }^{40}$ Circa 1344 illustrations in a 1338 manuscript of The Romance of Alexander, likely composed in England for an English audience, appear to represent a 'medieval glove-puppet show' performed on a miniature stage resembling a castle. ${ }^{41}$ Glove puppets were easily transportable and did not require an elaborate stage; for this reason, they were likely favoured by touring and travelling performers. 'In general', Speaight writes, 'it can be said that the marionette, requiring a fairly bulky and permanent type of stage, comes into prominence during periods of material prosperity, but that the glove and other more portable types of puppet tend to displace it in times of social unrest, when entertainers are forced into a vagabond life. 42

Only in the mid-sixteenth century does compelling evidence for the presence of marionette theatre in England begin to appear, when 'marvels' from the continent, particularly Italy, are noted in both civic and private records and in the literature. Most historians of the puppet theatre appear to agree that the early modern western European marionette likely originated in Italy and from there entered France and England, heavily influencing their the- 
atres. ${ }^{43}$ Evidence survives of sophisticated actions and dramas performed by marionettes in Italy by the 1550s. Speaight cites a mid-century description by Gerolamo Cardano of puppets 'able to "fight, hunt, dance, play at dice, blow the trumpet, and perform most artistically the part of cook"'. 'Even allowing for the exaggerations which all literary observers seem to consider appropriate to their descriptions of puppets,' Speaight concludes, 'it is clear that the Italian marionettes were by this time playing some quite elaborate dramas' ${ }^{4}{ }^{4}$

At almost exactly the same time, performances referred to as 'Italian motions' began to appear in England, initially performed by touring Italians, later by Englishmen. Speaight cautions that Italian motions were not always puppet plays, as clockwork automata were also referred to by this term, especially when toured and displayed in boxes as a retablo. But sometimes, they certainly were: 'Motions have been accepted as synonyms for puppets by all the competent authorities, and in many cases this is quite certainly the sense of the word', Speaight writes; whether puppet plays or not, 'they came in the first place from Italy. 46

The first reference to an Italian motion in England is in 1573, and the references continue until 1650:

the Privy Council requested the Lord Mayor of London to permit 'certain Italian players to make show of an instrument of strange motions'; the Italians evidently had friends at Court, for this request was followed by a sharp order within five days when the permission had not been granted. Between 1619 and 1640, there are continual references to Italian motions touring the countryside, like the three men and assistants who showed 'an Italian motion with divers and sundry stories in it' at Coventry; at Norwich an interesting point was raised when a man produced a licence to show an Italian motion, but because he said 'his motion was no Italian motion but made in London' he was not allowed to show it there. The term began to go out of use by about 1650 , and soon became archaic. ${ }^{46}$

Philip Butterworth, noting the same references, wonders 'What was an Italian motion? Was it different from existing notions of motions? Was it that such motions were performed by Italians? Or was the content or style Italian?'47

In the previous section a strange use of the adjective 'Italianate' was noted in William Thomas's The Pilgrim, used perhaps but not necessarily in reference to the Rood of Boxley: 'especially one Christ Italianate, that with the head answered yea and nay at all demands'. ${ }^{48}$ Thomas had before suggested 
that English images were unlike Italian images because most of the former moved through the use of internal engines. He then singled out one English image for discussion, citing it as a perfect example of the national type presumably because of its motions, yet describing it as Italianate. The choice of adjective seems nonsensical. We can wonder (with Butterworth) if perhaps the content or style of the crucifix was 'Italian.' 'Italianate' as an adjective at the time was used in this sense, but also in the sense of 'Catholic' or 'papist', 'foreign', 'corrupt'. Given the context, however, Thomas's criticism of the image for its feigned movements, it seems more likely that 'Italianate' refers to the motion of the image or Rood. If this is the case the Rood may have been unlike Italian religious images but like Italian marionettes, automata, 'motions'. Thomas may have been contrasting religious and theatrical functions and contexts for images.

John Hoker's 1538 representation of the image of Christ on the Boxley Rood as strolling player and of the crowd for whom he performed as theatrical audience is elaborated in William Lambarde's Perambulation. Hoker, writing before the establishment of permanent theatre buildings, compared the Royal Court, where the image 'salute[d] the king', to a generic theatre space. Lambarde, revising his 1570 manuscript for print publication in 1576, compared Boxley Abbey to a bear-baiting arena and an inn yard, and so to more contemporary public playing spaces. He describes what he claims was the procedure for gaining access to the Rood. First, pilgrims visiting the abbey were required to 'be shryuen of one of the Monkes'; second, they had to lift another image for which the abbey was famous, an image of 'Sainct Grumbald, for Sainct Rumwald' to prove that they 'were in cleane life (as they called it) or no'; finally, having completed both steps, the pilgrims were able to gain access to and 'haue benefit by the Roode of Grace'. ${ }^{49}$ Lambarde develops and explains his very similar (to Hoker's) but more contemporary figure:

But marke here (I beseeche you) their [the Boxley monks'] prettie policie in picking playne folkes purses. It was in vaine (as they persuaded) to presume to the Roode without shrifte, yea, and money lost there also, if you offer before you were in cleane life. And therefore, the matter was so handled, that without trebble oblation, (that is to say) first to the Confessour, then to Sainct Rumwald, and lastly to the Gracious Roode, the poore Pilgrimes coulde not assure them selues, of any good gayned by all their laboure: No more then suche as goe to Parisgardein, the Bell Sauage, or some other suche common place, to beholde Beare bayting, Enter- 
ludes, or Fence playe, can account of any pleasant spectacle, unlesse they first paye one penny at the gate, another at the entrie of the Scaffolde, and the thirde for a quiet standing. 50

Paris Garden existed as a bear-baiting arena from at least 1562, but the first extant references to theatrical activity in the Bell Savage Inn appear in 1576. Lambarde must have added the reference immediately before his manuscript was published. ${ }^{51}$

Lambarde does not mention puppet plays in his list of empty spectacles, but puppet plays were staged at Paris Garden by at least 1584, probably earlier, and certainly after. According to Speaight,

In 1584 Lupold von Wedel, a German visitor to England, described some kind of puppet show set up for comic relief in the circular arena here [at Paris Garden], after bull- and bear-baiting was over; it was 'a device in which a man displayed a number of little men and women, dancing, wrestling, and talking together; and at the end one of the little men threw pieces of white bread into the crowd, who scrambled to pick them up'. The entertainment concluded with a firework display. An oblique reference of 1592 to 'Paris Garden, wherein he will so tamper with the interpreter of the puppets' confirms the presence of puppet shows in this popular Elizabethan pleasure resort. ${ }^{52}$

Speaight concludes that because one of the puppets threw bread into the audience, it was most likely a glove puppet and not a marionette. However the mention of dancing suggests that other of the puppets had legs that could be manipulated.

Hoker and Lambarde both describe specifically the Rood and Boxley Abbey as theatrical object and context. Other writers and other works make more general connections between religious images and puppets. The Second Tome of Homilies ('Set out by the authoritie of the Queenes Maiestie: and to be read in euery parishe Church agreeably'53), published in 1577, refers repeatedly to religious images as puppets and, on occasion, as 'maumettes' in its 'Sermon agaynst Peryl of Idolatrie'. 'Puppet' and 'maumette' sometimes suggest 'doll', an alternate meaning of both words. For example the sermon cites and discusses Lactantius' criticism of idolatry in his Divine Institutes. Lactantius in his turn refers to Persius's second Satire, which mocks religious images, describing them as 'dolls' given to Venus by virgins. Lactantius writes: 
[Persius] subjected to ridicule the fact that there is 'gold in temples, that puppets are donated by a maiden to Venus'. These things Persius despised perhaps for their minuteness. He did not see that the statues themselves and the likenesses of the gods made by the hands of Polycleitus, Euphanor, and Phidias from gold and ivory, were nothing other than grand puppets, not given by maids to whose play pardon can be given, but dedicated by bearded men. ${ }^{54}$

The sense above and in the 'Sermon agaynst Peryl of Idolatrie' is clearly primarily that of doll, not puppet: 'Thus farre Lactantius, and muche more, to long here to rehearse, declaring, that as litle girles play with litle puppettes, so be these decked Images great puppettes for olde fooles to play with'. ${ }^{55} \mathrm{At}$ other times in the sermon, however, the theatrical sense is clear and primary. The sermon comments further on the use of images in Catholic worship and ritual:

And because the whole Pageaunt must throughly be playde, it is not yenough thus to decke idolles, but at the last come in the Priestes them selues, likewyse decked with golde and pearle, that they may be meete seruauntes for suche Lordes and Ladyes, and fyt worshippers of suche goddes and goddesses. And with a solemne pace they passe foorth before these golden puppets. ${ }^{56}$

The most common meaning of 'pageant' in the sixteenth century was 'play' or "theatrical spectacle', especially of a religious kind. The priests, excessively costumed like their 'idols' or 'puppets', engaged in theatrical performances that evinced a complicated religious and more broadly cultural corruption.

\section{The Rood as Sexual: the image/puppet and spiritual fornication}

Scott Cutler Shershow in Puppets and 'Popular' Culture demonstrates that within the Platonic or Realist aesthetic, the religious image or puppet was represented as 'pernicious both because it was a grossly inadequate attempt to represent the deity ... and in its presumptuous belief that human hands might invest a material figure with animate life. ${ }^{57}$ The image or puppet, in its materiality and in the manner in which it was used and enjoyed by human agents, became associated with the effeminate and the sexual, specifically with 'unnatural' or non-reproductive sexuality. Shershow cites Paul's first letter to the Romans (quoted more fully here): 
For the wrath of God is revealed from heaven against all ungodliness and wickedness of those who by their wickedness suppress the truth. For what can be known about God is plain to them, because God has shown it to them. Ever since the creation of the world his eternal power and divine nature, invisible though they are, have been understood and seen through the things he has made. So they are without excuse; for though they knew God, they did not honor him as God or give thanks to him, but they became futile in their thinking, and their senseless minds were darkened. Claiming to be wise, they became fools; and they exchanged the glory of the immortal God for images resembling a mortal human being, or birds or four-footed animals or reptiles.

Therefore God gave them up in the lusts of their hearts to impurity, to the degrading of their bodies among themselves, because they exchanged the truth about God for a lie and worshiped and served the creature rather than the Creator, who is blessed forever! Amen.

For this reason God gave them up to degrading passions. Their women exchanged natural intercourse for unnatural, and in the same way also the men, giving up natural intercourse with women, were consumed with passion for one another. Men committed shameless acts with men and received in their own persons the due penalty for their error.

(NIV Romans 1.18-27)

Shershow explains:

to worship the inanimate matter of the graven image is to degrade not just one's spiritual understanding but one's material flesh. The presumptuous attempt to represent God's transcendent truth in a merely human image, like the promiscuous sexuality which is both a mirror and a consequence of that attempt, is a subversion of the hierarchy of being and creation, serving 'the creature more than the Creator'. ${ }^{58}$

The 'Sermon agaynst Peryl of Idolatrie' in The Second Tome of Homilies describes the use of 'idols' in religious worship and ceremony as 'spiritual fornication', and the images themselves as 'strumpets and harlots'. To prefer to love and worship an image, an inanimate thing, a resemblance, is to love and worship inappropriately, unnaturally, perversely. An individual who commits 
this kind of act alone and in a private place is sinful enough. If he performs this act in public and encourages others to commit similar acts, he becomes still worse, a procurer, a pimp:

And as he were the enimie of all honestie, that woulde bryng strumpettes and harlottes out of their secrete corners into the publique markette place, there freely to dwel and occupie theyr filthie marchaundise: So is he the enimie of the true woorshipping of God, that bryngeth idolles and images into the Temple and Churche, the house of God, there openly to be worshipped, and to spoyle the zelous GOD of his honour, who wyll not geue it to any other, nor his glorye to caruen Images, who is as muche forsaken, and the bond of loue betweene man and hym as muche broken by idolatrie, whiche is spiritual fornication, as is the knotte and bonde of mariage broken by carnall fornication. ... Nowe he that wyll bryng these spirituall harlottes out of theyr lurkyng corners, into publique Churches and Temples, that spirituall fornication maye there openlye of al men and women without shame be committed with them, no doubte that person is cursed of GOD, and twyse cursed, and al good and godly men and women wyl say Amen, and their Amen wyll take effect also. ${ }^{59}$

Images themselves are feminine because material, not spiritual, and because manipulated as objects by external agents positioned above them in the social and ontological hierarchy. ${ }^{60}$ Images of male saints are rendered exotic by their decoration and dress while images of female saints are by the same treatment (again) reduced to harlots and whores. The 'Sermon agaynst Peryl of Idolatrie' complains that

Our Churches stande full of suche great puppettes, wonderously decked and adourned, Garlandes and Coronettes be set on their heades, precious pearles hangyng about their neckes, theyr fingers shine with rynges, set with precious stones, their dead and stiffe bodyes are clothed with garmentes styffe with golde. You woulde beleeue that the images of our men saintes, were some princes of Persie lande with their proude apparell, and the idolles of our women saintes, were nice and wel trimmed harlottes, temptyng theyr paramours to wantonnesse. ${ }^{61}$

Those who worship and manipulate these images are in their turn feminized. Shershow analyses Lactantius's comment (cited in the previous section of this article) on Persius's second Satire. Persius at the end of this Satire made reference to 'puppets ... donated by a maiden to Venus' ${ }^{62}$ According to Lac- 
tantius, Persius 'did not see that the statues themselves and the likenesses of the gods ... were nothing other than grand puppets, not given by maids to whose play pardon can be given, but dedicated by bearded men'. ${ }^{63}$ Shershow explains:

Here the traditional link between the subject and the object of idolatry takes on a sexual and familial dimension: the 'bearded men' with their grand divine images are like girls with their dolls. Lactantius' rhetorical conceit projects a kind of ironically double spatial symmetry: the idols are both overgrown puppets and incongruously diminutive images of the deities they are presumed to represent. But Lactantius also subdivides the basic binary distinctions between large and small, animate and inanimate, human and divine, on which his rhetorical conceit depends, into a full hierarchy of social and sexual difference. Lactantius' irony implicitly affirms that the (male) sculptors and dedicators ought to be both socially and ontologically 'higher' than the female figures here envisioned either as girls at play or as maidens taking part in a sexual or procreative ritual .... The act of idolatry-the specific confusion of presence and representation-induces an analogous cultural or psychological confusion between the child and the man, the man and the maid. ${ }^{64}$

In the case of the Rood of Boxley, those pilgrims who believed in its miracles were reduced to the state of women, children, and weak, impotent men and further were by implication sexually compromised, at least according to protestant reformers. Lambarde in his Perambulation, when representing the pilgrims who flocked to Boxley Abbey, focused on children and women and on their reactions to and relations with the image of St. Rumwald, which functioned as a test of purity of life. As mentioned before, according to Lambarde, if a pilgrim could lift this image he or she was shown to be of clean life and therefore acceptable in turn to the miraculous Rood. Lambarde describes this image of Rumwald as 'so small, hollow, and light, that a childe of seuen yeares of age might easily lift it'. ${ }^{65}$ However, he qualifies and explains immediately, by means of a 'pyn of wood, stricken through it into a poste (whiche a false knaue standing behinde, coulde put in, and pull out, at his pleasure)', the image could be immobilized. Lambarde notes that at times this trick 'moued more laughter, then deuotion, to beholde a great lubber to lift at that in vayne, whiche a young boy or wenche had easily taken up before him'. More ominous and less amusing, 'chaste Virgines, and honest marryed matrones, went oftentimes away with blushing faces, leauing (without cause) in 
the myndes of the lookers on, suspicion of uncleane life, and wanton behauiour'. The monks used this fear to exhort more money from female pilgrims than from male: 'for feare of whiche note and villanie, women (of all other) stretched their purse strings, and sought by liberall offering, to make Sainct Rumwalds man their good friend and Maister'. ${ }^{66}$

Lambarde suggests that the monks' tricks unfairly implied sexual impropriety and that women paid to avoid undeserved reproach. However the women's desire to interact with the images of Rumwald and the Rood suggests these pilgrims, if physically chaste, were not spiritually chaste. Lambarde's representation of the Rood itself is starkly sexual: after his description of the creation of the Rood of Boxley by the carpenter he suggests that its 'generation' is 'comparable ... to the creation of that olde beastly Idol Priapus'. Of this idol 'the Poet Sayth':

A Figtree blocke sometime I was

A $\log$ vnmeete for use:

Til Caruer doubting with him selfe,

WERT BEST MAKE PRIAPVS,

OR ELSE A BENCHE? resolude at last

To make a God of me:

Thencefoorth a God I am, of birdes

And theeues most drad, you see. ${ }^{67}$

A sculpture of Priapus, of course, would have displayed an enormous erection-but at the whim of the carver that same image could have been an object without sex or gender, an 'it', a bench. A show of masculinity could not render an image masculine but might attract as empty spectacle the foolish and naïve.

Like the religious image the puppet was feminine and sexual because of its nature as material artistic object. This nature was either reflected in or reinforced by the apparent bawdiness of some early puppet play narratives. ${ }^{6} 8$ The first mention of an English puppet play that suggests possible content is a reference to a production based in Grimsby. In 1431, John de Rasyn brought legal action against Hans Speryng for not delivering to him by an agreed-upon date 'certain instruments of play called Joly Walte and Malkyng. ${ }^{69}$ Ian Lancashire reads the record of this complaint, listed in the court rolls for 3 September, as evidence that John de Rasyn and Hans Speryng were both puppeteers and that the instruments mentioned in the suit were pup- 
pets shared between them. He speculates that John perhaps sought damages incurred when Hans returned late from a summer tour or that the two men may have fallen into a disagreement over possession of the puppets. No text of the puppet performance or play survives, but Lancashire believes that the names of the puppet characters suggest a general subject and content. $\mathrm{He}$ writes: 'The puppet play [of Joly Walte and Malkyng] seems to be related to the fragmentary, early fourteenth-century Interludium de Clerico et Puella, our oldest English play-text and of northern provenance. It tells of a lusty cleric wooing a girl called (he says) "mayden Malkyn" who lives "at the tounes ende" (11. 47, 49)'. Lancashire notes further that 'From about 1250 at least, a proverbial figure Malkin suffered by being labeled both the unwanted virgin and the easy woman'.He offers among other examples Malyne in the Reeve's Tale, the miller's daughter seduced — or raped-by the cleric Aleyn. 'If our puppet Malkyng was a descendant of this poor wench,' Lancashire conjectures, 'and her companion Walt lived the "joly lyf" that the Reeve's Aleyn enjoyed with his Malyne (A 4232), the puppet play was a straightforward comedy of seduction and clerical incontinence'. ${ }^{70}$

In The Blind Beggar of Bednal (Bethnall) Green, by Chettle and Day (1600), we find a clearer description of the content of a puppet play, though fictional and satirical. In this text the character Canby, who has temporarily disguised himself as a puppeteer, advertises the kinds of entertainment that his audience will see:

Gentlemen the first conceit you are to see is Tumbling. ... You shall likewise see the famous City of Norwitch, and the stabbing of Julius Caesar in the French Capitol by a sort of Dutch Mesapotamians. ... [Y] ou shall likewise see the amorous conceits and Love songs betwixt Captain Pod of Py-corner, and Mrs Rump of Ram-alley, never described before. ... Or if it please you shall see a stately combate betwixt Tamberlayn the Great, and the Duke of Guyso the less, perform'd on the Olympick Hills in France. ${ }^{71}$

Canby's puppet play consists of violent historical events, represented obviously imperfectly, and a 'romance' in mock-epic style between two inhabitants of Smithfield, Captain Pod and Mrs. Rump. The name Pod is suggestive: at the time 'pod' referred either to 'the socket of a brace in which the end of the bit is inserted' or to a 'young jack or pike (fish)' (OED). Pie corner, named for the Magpie inn, was located in Smithfield, just off Cock's Alley, and was notorious as a place where prostitutes plied their trade, suggesting that Pod 
either frequented or managed the whores there. Mrs. Rump is metonymically reduced to her most important feature ('Rump' may suggest anal and so non-reproductive sex). 'Ram Alley', which connected Fleet Street to the Temple, was known for its crime and for its sexual commerce. Lording Barry represented this street and the various activities that occurred there in his play Ram-Alley or Merrie-Trickes, played at Whitefriars in 1610 by the Children of the King's Revels. The 'Merrie Trickes' played out in the text include a marriage contracted under false pretense and the wooing of a lusty widow by both a father and a son (the son wins by forcing the widow to choose between marriage with him or death). Throte, a greedy lawyer tricked over the course of the play into marrying a prostitute he mistakes for a nobleman's virginal daughter, evokes for his audience the character of the neighbourhood when he asks Horatio Boutcher and others,

[A]re you mad?

Come you to seeke a Virgin in Ram-alley:

So neere an Inne of Court and amongst Cookes,

Ale-men and Landresses? why are you fooles? ${ }^{72}$

Ben Jonson's Bartholmew Fair (1614) offers another example of the kind of narrative apparently typical in early modern puppet theatre. The puppet play within Jonson's play presents the story of Hero and Leander; the subject matter then is obviously sexual, as the myth centers on an act of seduction. The conditions of production are sexualized as well as Bartholmew Cokes, the too-eager audience of the play, pulls the puppets out of a basket and plays with them before the performance begins (Speaight suggests on this evidence that the puppets are glove puppets, not marionettes ${ }^{73}$ ). Cokes asks Leatherhead, the interpreter or master of the puppets, which of them is his 'best actor' (5.3.75) ${ }^{74}$ Leatherhead identifies the puppet that 'acts young Leander' and describes him as 'extremely beloved of the womenkind, they do so affect his action, the green gamesters that come here' (77-9). Puppet Leander's masculine appearance and 'action' or movements, which fascinate the loose women in the crowd, do not attract Cokes. He is more interested in the puppet that plays Hero. In the following scene, the stage directions describe him 'handling the puppets' (5.4.4); when Leatherhead objects to this fondling Cokes protests that he will not 'hurt her' (Puppet Hero) and that his actions are not dishonourable or dishonouring. 'I pray thee be not jealous', he entreats; 'I am toward a wife' (6). 
Once the play begins the puppets all become sexually aggressive agents and abusive toward Leatherhead the interpreter. Puppet Leander tells Leatherhead almost immediately, 'kiss my hole here, and smell' (120). Puppet Damon, who arrives at the alehouse for a sexual dalliance with Hero, shares insults with Puppet Pythias: they call each other 'whoremasterly slave', 'Whoremaster', 'pimp' and 'scab' $(201,203,209)$. Meanwhile Puppet Hero, 'pricked' by $\mathrm{Cu}-$ pid, is upstairs having sex with Puppet Leander. Leatherhead explains exactly how she was seduced: 'Cupid, distinguished like Jonas the drawer, / From under his apron, where his lechery lurks, / Put love in her sack' (247-9). He either charmed her wine (sack) or inserted 'love' into her vagina. The sexual innuendo continues throughout the scene. When Puppet Leander instructs Puppet Hero to leave a candle's end burning in her window to guide him as he swims to her across the Thames, she answers, 'I protest I should handle / My matters very ill, if I had not a whole candle' (263-4). Puppets Damon and Pythias arrive carrying a side of bacon 'under their cloaks' to Puppet Hero; Leatherhead, who knows she is upstairs with Puppet Leander, tells them that Hero will not be interested in their gift. Finally Puppets Hero and Leander are discovered kissing, 'Kiss, kiss upon kiss' (274). All of the puppets begin to battle, calling one another 'whore', 'knave', and 'whoremaster'.

The sexual nature of images or puppets and of their narratives perhaps helps to make sense of the often noted but never carefully discussed portrayal of the Rood of Boxley in Grey's 1563 'The Fantasie of Idolatrie'. The tragic (yet debased) love story presented in this ballad seems typical of the kinds and styles of narratives familiar to audiences of the puppet theatre: for example as in Chettle and Day's and Jonson's satirical representations, in 'The Fantasie of Idolatrie' we see the mythic mixed with the homely and the epic reduced to the mundane. We are told that the image of Christ repeatedly, during its tenancy at the abbey, climbed down from the cross to meet together with Our Lady in the middle of the night. Star-crossed lovers, they 'Should haue bene maried' but 'taried / To spie a tyme howe and whan'. ${ }^{75}$ Their romance sounds very much like that of Hero and Leander:

As ij. louers eche other loue to procure

They did mete very oft

Wherby it was thought

That our Lady and he had bene sure.

Now the rode is dead

And can not her wed

Death gaue him so sore a stroke. ${ }^{76}$ 
It sounds equally sexual as well: they meet 'eche other loue to procure', which suggests that their relationship has been consummated.

The Rood's sexual nature (as a kind of Priapus perhaps, as suggested by Lambarde) is made more explicit after the short account of his 'death'. Grey notes that if the Rood and Our Lady had been married, because of her wealth they would have been well off, even if the Rood had never worked 'but lyke an Idoll lurked'. And yet he had his own talent for making money:

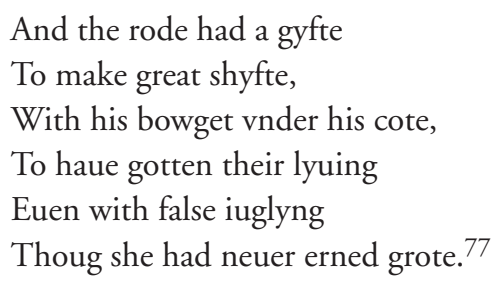

This passage appears to carry figurative as well as literal meaning. The Rood hid his 'bowget' (budget) or purse under his coat ${ }^{78}$ perhaps to disguise his wealth, his deceptive apparent poverty encouraging pilgrims to offer him donations. Alternately he concealed a juggler's budget under his cloak to help him perform magic tricks or 'miracles', these tricks in turn encouraging pilgrims to offer him money in exchange for blessings and acts of healing. ${ }^{79}$ These deceits would have allowed the Rood to support his wife in the manner to which she had become accustomed - if she hadn't happened to be obscenely rich herself (the implied excess of goods is represented as particularly heinous). At the same time the reference to the Rood's budget concealed beneath his cloak certainly carries a bawdy meaning: 'budget' is a clear and constant metaphor for both testicles and penis. The Rood concealed his genitals beneath his coat just as Puppet Damon and Puppet Pythias in Bartholmew Fair conceal their 'bacon a gammon' under their cloaks (5.4.267). Strictly speaking, as an image the Rood should not have had a penis, as it would not have been necessary or (one would assume) functional. At best, his penis could have operated as a symbol, a sign of Christ's masculinity and power. ${ }^{80}$ But then the penis, if it could not have been openly displayed, could not have been completely concealed: how then would it signify? Given the context of the romance, the Rood (it is implied) used his penis to satisfy his wife not to signify his power; instead of 'lurking' or shirking work and idling, the 'idol' earned his living by 'shifting'- 'bestirring' himself. Grey suggests that the Rood could (if necessary) have exchanged sexual favours with Our Lady of Walsingham for 
money, adding yet another nuance to the sacrilegious representation the ballad constructs of the relationship: as a commercial exchange as well as an act of incest, a reduction to the literal of the Virgin as figurative lover of Christ (as well as literal mother).

Grey might suggest further that the image earned its money through a kind of general figurative prostitution. Images of female saints in The Second Tome of Homilies are described as harlots while images of male saints are described as exotics (in part because of their dress, and in the ballad Christ wears a coat). The general cultural construction of images was not incompatible with a representation of the Rood as not gigolo but male prostitute. Finally the hidden 'budget' and its ambiguous connection to the Rood's 'great shyfte' to make his and his lover's 'lyuing' may imply that pilgrims who flocked to Boxley Abbey and gladly made their offerings were paying to be (figuratively) 'screwed' by the image and by the monks orchestrating the supposed deception.

Reformers in contrast, understanding the true nature of images, were not fooled by their artificial masculinity. Images were merely impotent feminine objects, puppets unable to do anything for themselves, dependent upon external masculine agents:

But now may we see

What Goddes they be,

Euen puppets, mamats, and elfes,

Throw them downe thryse

They can not aryse

Not ones to helpe them selues. ${ }^{81}$

\section{The Ignorant/Naïve Narrator/Pilgrim: the Rood and right reading}

As noted above in the examples from Chettle and Day, Jonson, and Grey, the 'puppet' and the image are ridiculous because diminutions of heroic and mythic, even religious, figures. They reduce their referents in part because of their own physical nature (images and puppets are copies and are generally literally smaller and more imperfect than their originals) and in part because of the assumed (and constructed) ignorance of their audiences. In Ben Jonson's Bartholmew Fair the character Cokes, representative of puppet audiences, wonders whether the puppet show of Leander and Hero will be played 'according to the printed book', which he has read (5.3.93-4). Leatherhead, the interpreter of the play, answers 'By no means, sir. ... That is too learned 
and poetical for our audience. ... No, I have entreated Master Littlewit to take a little pains to reduce it to a more familiar strain for our people' (95, 97-8, 102-3). This reduction consists of substituting the river Thames for Hellespont and making Leander 'a dyer's son, about Puddle Wharf; and Hero a wench o' the Bankside' (108-10).

Leatherhead and Little consider these changes necessary because of the limitations of their audiences. They believe their spectators to be uneducated and naïve, though the two characteristics do not necessarily 'go' together: for example Cokes, who has read and is familiar with the original story of Leander and Hero, is gullible and seems to have difficulty understanding the conventions of puppet theatre. Shershow argues that whatever the reality of the early modern puppet show's audience demographic, playwrights like Jonson represented puppet spectators as ignorant and simple in order to construct and maintain a hierarchical concept of theatre and of society. Puppet theatre is 'for Jonson a paradigm of low, popular culture in its subordination to a drama newly conceived of as literary'. ${ }^{82}$ Jonson likely did not originate the paradigm but developed further one that was already to some degree familiar.

A late example not discussed by Shershow gives us a sense of the kinds of audiences drawn to puppet plays. A 1630 entry in the Dorset Quarter Sessions Order Book for 1625-37 records a complaint against William Sandes, his two sons, and nine others who travelled to Beaminster to present a puppet show. Their performances caused considerable disruption in a particular segment of the population:

And whereas the Constable of Beaminster in this County and other inhabitants there haue now alsoe informed this Court that the said William Sands thelder and his Company are come to Beaminster aforesaid and there haue sett vp their shewes of poppett playinge, and there doe exercise their feats not only in the day tyme but alsoe late in the night to the great disturbance of the Townsmen there, and the grievance of diuers of the Inhabitants who cannot keepe their Children and servants in their houses by reason that they frequent the said shewes and sights late in the night in a disorderly manner. ${ }^{83}$

Children and servants flocked to the performances, which were sites and occasions of social chaos (strangely appropriate since one of Sandes' plays was entitled The Chaos of the World).

In reformed representations generally and specifically in reference to the Rood of Boxley, pilgrims who flocked to shrines to worship images were simi- 
larly portrayed as simple and naïve, foolish, blind, stupid, childish. John Finch in his 1538 letter writes, 'There were, after this, exhibited many other tricks of the same kind, by which the simple were imposed upon by the priests; so that the ignorant people now call them mere conjurors' ${ }^{84}$ Thomas's The Pilgrim, discussing a number of alleged miracles including perhaps the movements of the Rood of Boxley, offers a particularly harsh representation of those who believed:

For all the miracles that the blind people conceive to proceed from these images, or by means of these represented saints, are clean repugnant to the Christian faith, and also unto God's perfection. ... But the ignorant multitude that are always more inclinable unto error than unto the truth, have tasted such a savour in their imaginations, that because God commonly granteth not the things that they most desire, they therefore have framed gods that will do for them when they be prayed unto, believing the better to attain their purpose by many than by one.

And hereof hath it followed that when some person hath escaped any imminent danger, recovered health from a grievous sickness, or cure of a sore wound, passed some dangerous tempests of the sea, or obtained some victory in arms, or some riches or possessions, incontinently he yieldeth thanks therefore unto his familiar advocate in heaven, by whose means he imagineth to have received such benefits; which otherwise the mutable God, as he believeth, would never have granted him; and therefore runneth to this or that image with candles, torches, lamps, incense, bells, and a thousand other tricks; affirming this and that miracle, which in effect are no other but their false and ignorant imaginations. And as to the burning of lights before those images, it is so foolish a thing that meseemeth it rather meriteth to be laughed at than spoken against. ... But what need I thus to occupy myself with those foolish saints and pilgrims, since the thing is now so manifest unto all men that have eyes, that who is he that cannot, with reason, beside the authority of the Scriptures, confound this ignorance? ${ }^{85}$

In Grey's ballad 'The Fantasie of Idolatrie', pilgrims in general are ridiculed as willfully ignorant:

But we of a stoubourne mynd

Be so harde harted

Wyll not be conuerted

But rather styll be blynde, 


\author{
Ronnyng hyther and thyther \\ We can not tell whether, \\ In offryng candels and pence, \\ To stones and stockes \\ And to olde rotten blockes \\ That came, we know not fro $m$ whense. ${ }^{86}$
}

The poet continues, describing pilgrims 'To Walsyngham a gaddyng / To Cantorbury a maddyng, / As men distraught of mynde'. The Rood's tragic love affair with Our Lady appeals only to the silly and ignorant; further it is a product of their romantic (idolatrous) fantasies. The ballad frames its story carefully: 'The saying was / That this rode of grace / And our Lady of Walsyngham / Should haue bene maried'; 'If the people say ryght / As ij. louers eche other loue to procure / They did mete very oft / Wherby it was thought / That our Lady and he had bene sure'. Elsewhere Grey, the author of the ballad, adopts a voice that appears to position him among the 'juggled': 'Yet haue we thought / That these Idols haue wrought / Myracles in many a place'. ${ }^{87}$ However his representation of the puppet romance as a kind of early modern urban myth, generated within and transmitted by the ignorant masses, evinces a distanced contempt for audiences of popular entertainments. ${ }^{88}$

Puppet audiences and religious pilgrims in their representation seem to have resembled each other in their gullibility, their fondness for spectacle, and their inability to understand and observe simple rules of aesthetic decorum. They were for example allegedly unable to comprehend that the translation of Hero and Leander into London citizens of the lowest, meanest sort deconstructs the myth and that a conventional romance between Christ and his mother is blasphemous. If audiences and pilgrims were to be freed from their misunderstandings and misconceptions, they needed to be educated, to be taught a proper method of reading. In Bartholmew Fair Cokes needs to be taught that Leatherhead, even when he appears to be out of control of the action taking place on the puppet stage, is in fact master of the puppets: when Puppet Pythias and Puppet Damon attack Leatherhead, Cokes asks, 'How is it, friend, ha' they hurt thee?' Leatherhead replies, 'O no! / Between you and I, sir, we do but make shew' (5.4.234-5). Cokes, not entirely understanding, remarks, 'Well, we have seen't, and thou hast felt it, whatsoever thou sayest'(242-3).

In 'The Fantasie of Idolatrie' pilgrims need to be taught Old and New Testament scripture to understand the true nature of 'idols': 
The Prophetes all

In generall

Of Idols as we may se

Put vs from doubte

And set them out

In their colours as they ought to be

Saynt Paule also

With many saintes mo,

Against Idols with al their myght

Perceiuing suche swarmes

Did blase their armes [describe them heraldically]

And brought them out to lyght. ${ }^{89}$

This deliberate juxtaposition of images and the scriptures seems designed to refute the common defence of the former as 'lewd men's books' and so educational tools essential to the religious instruction of the illiterate. Images are represented as objects more likely to corrupt and imperil than to instruct, and the uneducated and simple are represented as particularly vulnerable. In The Second Tome of Homilies the 'Sermon agaynst Peryl of Idolatrie' asks, 'howe shoulde the unlearned, simple, and foolysh, scape the nettes and snares of idolles and Images, in the whiche the wysest and best learned haue been so entangled, trapped, and wrapped?'. Scripture warns of danger to 'infinite multitudes and millions of idiots and unlearned, the ignorant and grosse people, lyke unto Horses \& Mules in whom is no understandyng, whose peril and daunger to fal on heapes to idolatrie by occasian of Images' 90

Discussions of the exposure of 'false' images in accounts of the Rood of Boxley seem preoccupied generally with the establishment of 'facts' and of 'truths'. These facts and truths may be obtained through empirical observation and/or through careful study and comprehension of the Bible as translated into English and explicated in sermons. John Finch writes to Conrad Humpard:

A certain German merchant here, who is well acquainted with the English language, told me as a certain fact, that all the images, which used to work miracles by the artifices of the devil and his angels, that is to say, the monks, friars, fisheaters, and others of that stamp, were conveyed on horseback to London, at the command of the bishops: that a public sermon was preached from the pulpit of St Paul's to the congregation assembled in Christ; after which a certain image 
brought away from Kent, and called in English 'The rood of grace in Kent', was first exhibited. The preacher, the bishop of Rochester, explained all the trickery and imposture in the presence of the people. ${ }^{91}$

Ignorance, a characteristic of the masses attracted both to miraculous images and puppet dramas, is a product of misreading and misunderstanding, the kind facilitated by the miscomprehension of language. Finch emphasizes that because the merchant has mastered the English language the information he has presented about the Rood of Boxley must be factual. This merchant understood accounts of the sermon explicating the nature of the image, a sermon itself in English. Misunderstanding is replaced by perfect understanding, which is transmitted next through the written word in Finch's letter.

A striking and likely not coincidental addendum to more than one account of the destruction of the Rood is the religious imperative, either merely noted or endorsed, that people generally and/or the audience at Paul's Cross learn their Pater Noster in English. The London Chronicle during the Reigns of Henry the Seventh and Henry the Eighth, after its accounts of the destruction of the Rood of Boxley and of other images (for example at 'Barmsey Abbey' and 'Walis') and of the shrine of Saint Thomas of Canterbury, notes that 'Then was every man, woman, and child commaundid to lerne ther patar noster, ave and crede, in Englissche'. The chronicle continues: 'Then hit was commaundid that no light should be set in churches a fore no Image, but alle take a waye'. ${ }^{2}$ Wriothesley's chronicle offers a similar link and juxtaposition, between deception and misunderstanding and perfect comprehension:

Allso the sayde roode was sett in the markett place first at Maydstone, and there shewed openlye to the people the craft of movinge the eyes and lipps, that all the people there might see the illusion that had bene used in the sayde image by the monckes of the saide place of manye yeares tyme out of mynde, whereby they had gotten great riches in deceavinge the people thinckinge that the sayde image had so moved by the power of God, which now playnlye appeared to the contrarye.

Allso it was proclaymed in the Starre-Chamber at Westminster, the last end of Hilarie Terme, in the presence of the Lord Chauncellor and the Lordes of the Kinges Councell, with divers Justices of the Peace of diverse shires in Englande, that the sayde justices shoulde causse the Bible and Testament in Englishe to be had in their shires, and see that the curates and priests should preach the worde of 
God syncerelye and trulie to the people, and suffer the people to have the Bible and Testament in Englishe. ${ }^{93}$

Once the inner workings of the image had been exposed and direct experience and empirical observation had been interpreted in the light of scripture (in turn 'exposed' through translation into the vernacular), one final task remained. First hand experiences and accounts of the deception had, in order to reach wider audiences for a longer period of time, to be recorded, printed, and circulated - and they were. Writing more than thirty years after the Rood's destruction, William Lambarde suggested that reports, spread locally by word of mouth and more widely in print, had almost (but not quite) rendered his own account of the deception unnecessary: 'I shall not neede to report, howe leudely these Monkes, to their owne enriching, and the spoyle of Gods people, abused this wooden God after they had thus gotten him, bycause a great sorte be yet on liue, that sawe the fraude openly detected at Paules Crosse, and others maye reade it disclosed in bookes extant, and commonly abroade'. ${ }^{94}$

\section{The Catholic Pilgrim: the Rood and right reading}

The underlying assumption of the dichotomy assumed by Butterworth in his study (discussed in the introduction to this paper) and by the reformers who described and decried the Rood of Boxley seems to be that magic and miracle should inspire only serious, if misguided, belief while representation and theatre should inspire only disbelief and enjoyment of spectacle, in full appreciation of the distance between the image and its referent. One cannot (or at least did not) disbelieve and enjoy the magical or miraculous, and believe and enjoy the theatrical.

In this concluding section we need to ask finally whether pilgrims were actually 'deceived' by the Rood of Boxley's reported movements, thinking they were effected by God and in this way (and not as representation) were 'miraculous'. Some pilgrims may have been, in a manner similar to Cokes's naïve response to the puppet play in Jonson's Bartholmew Fair. At the same time, it seems other spectators understood that the movements of images were not always and necessarily effected by divine agents: they understood the internal workings of these devices and yet still appreciated these images and their movements in some more complicated way. Robert Shrimpton, born around 1505, remembered a 'hollow' image 'erected near St. Alban's shrine, 
wherein one being placed to govern the wires, the eyes would move and head nod, according as he liked or disliked the offering, and being young he had many times crept into the hollow part thereof' ${ }^{95}$ This account is instructive less about the mechanics of the image than about their familiarity to the local congregation: Robert Shrimpton as a child (or at least when he was young) repeatedly crawled into the image and so understood how it worked. He was unlikely the only person aware of the mechanical nature of the image. And yet it seems the object continued to be used, nodding and moving its head in response to offerings. What might have been the spectators' various responses to this image? Probably its movements did not (often) inspire belief that they were miraculous but rather enjoyment, and perhaps recognition, even laughter, when the donations offered were insufficient. Yet John Foxe, confusing in his Acts and Monuments an image like (or even the image of) St. Alban's for the Rood of Boxley, does not contemplate the possibility that those engaging with the image understood how it worked:

What posteritie will euer thinke the Churche of the Pope pretendyng such Religion, to haue bene so wicked, so long to abuse the peoples eyes, with an old rooten stocke (called ye roode of grace) wher in a man should stand inclosed with an hundreth wyers within ye roode, to make the Image goggle with ye eyes, to nodde with his head, to hang the lyppe, to moue and shake his iawes, accordyng as the value was of the gift whiche was offered? If it were a small peece of siluer, he would hang a frownyng lyppe: if it were a peece of gold, the $n$ should his iawes go merely. Thus miserably was the people of Christ abused, their soules seduced, their senses begyled, and their purses spoyled, till this Idolatrous forgery at last, by Cromwels meanes was disclosed. ${ }^{96}$

There is evidence to suggest that the Rood at Boxley was acknowledged and understood, even advertised, to be a mechanical marvel and further that the Rood's movements were of secondary attraction to the pilgrims who travelled and paid homage to it. J. Brownbill in 1883 and T.E. Bridgett in 1888 both noted this evidence, offering the same interpretation, and subsequent discussions of the Rood have not sufficiently considered their point. Brownbill and Bridgett draw our attention to Lambarde's account of the Rood's origin and history, specifically of the beginning of its residency at the abbey. Lambarde's source for the story was the monks themselves: 'I will set downe in suche sorte onely, as the same was sometime by them selues published in printe (as it is sure) for their estimation and credite, and yet remayneth deepely imprinted 
in the mynds and memories of many on liue, to their euerlasting reproche, shame, and confusion'. ${ }^{97}$

So the story goes, Lambarde writes, after the carpenter completed construction of the Rood in France he returned home with it to England. To transport it more easily he put it on the back of a 'Jade'. Stopping at an alehouse in Rochester, the carpenter allowed the horse to go ahead without him while he enjoyed some refreshment. The horse, under the influence of divine inspiration, left their intended route and instead travelled straight south to the abbey church at Boxley. There he stopped. When the monks came out to investigate, the horse rushed past them into the church and stopped only when he reached a central pillar. Realizing what the horse carried on its back, the monks began to remove the image in order to claim it. Just at this moment however the carpenter arrived and demanded that the monks give back the image and the horse. After determining that the carpenter was the owner of both, the monks agreed to let him go on his way, but no matter how he beat or pulled on the horse it would not move. The carpenter removed the image, thinking to carry it away himself, but the Rood 'also cleaued so fast to the place, that notwithstanding all that euer he and the Monkes also, (which at the length were contented for pities sake to helpe him) coulde doe, it woulde not be moued one inche from it'. ${ }^{98}$ The Rood remained in the abbey church from that point in time.

Lambarde claimed that the above account had been published by the monks of Boxley themselves and that the story had been committed to print 'for their estimation and credite'. 99 'What is the substance of this story?' Bridgett asks. 'It is that, as regards the Rood itself, there was no attempt whatever at concealment or imposture. It was published abroad by the monks that the Rood was the work of a clever carpenter, that it was a piece of mechanism. There was no pretence that its movements were miraculous'. ${ }^{110}$ Bridgett's point here is difficult to dismiss. Even if Lambarde's claim that the story originated with the monks was false, if Lambarde the antiquarian either accepted or manufactured a false source when writing his own text, this 'source' effectively deconstructs the accusation of deception. The primary miracle in this account, the monks' or Lambarde's or that of some third source, is not the fact of the Rood's movements but rather the events surrounding its arrival and installation in the monastery. Brownbill writes, 'the real reason why the image was supposed to be miraculous, was the extraordinary way in which the monastery had acquired it'. ${ }^{101}$ If the source of the story was the monks' own 'published' text (now lost), as Lambarde claimed, the story must have 
been important to the abbey's status as pilgrimage site. Subsequent miracles, if the monks claimed further miracles, could well have been of healing or other types of blessings.

These blessings may have been as simple (or complex) as personal affective responses to the images of the Rood and of St. Rumwald as representations: as objects like puppets in that their operators - unseen or seen-and internal 'operations' were recognized, but also like other kinds of religious images in that they inspired a faith and a belief not related to or dependent upon deception. Susan Verdi Webster introduces her study Art and Ritual in Golden-Age Spain with a striking illustration: the story of the artist Juan Martínez Montañés who, at the beginning of the seventeenth century, was commissioned by the confraternity of La Pasión to sculpt an image of Christ carrying the cross. Verdi Webster writes: 'According to legend, when the great artist saw the sculpture being borne in procession for the first time, he followed it through the streets, crying out in amazement that it was impossible that he could have created such an expressive and devout image'. Verdi Webster wonders how we might account for the sculptor's reaction to his own creation. 'Surely the artist, more than anyone else, had an intimate familiarity with the work of his own hands.... Given the circumstances, it would appear that the ritual context of the procession so profoundly affected and transformed the sculpture as to elevate it beyond the status of a carved wooden object, and that only within the context of the procession was the sculpture fully realized'. ${ }^{102}$ The material reality of the image, of the fact and nature of its construction, was not completely irrelevant to its effect but apparently insignificant in relation to its use and environment, its ritual function and context.

Juan Martínez Montañés was astonished at his own creation, which as a material object stood as evidence of divine inspiration and grace working through him as an artist. Within its ritual context the image, because of its expressiveness, elevated the observer's thoughts from the material to the spiritual and reminded him or her of God and his saints - the desired function of religious images according to Reginald Pecock, who describes them as 'rememoratijf or mynding signes'. ${ }^{103}$ And the image most effective in this function was the image that resembled Christ most closely. Pecock in a problematic passage from the Repressor justifies the use of images by comparing them to the sacraments:

If and whanne it is leeful and expedient forto haue and vse eny seable rememoratijf signes being lasse lijk to the thingis signified, it is leeful and expedient forto 
make, haue, and vse signes being more like to the same thingis signified. Forwhi the likenes of a signe to his significat, (that is to seie, to the thing signified bi him,) wole helpe the signe forto signifie and forto make remembraunce the bettir upon the thing signified; but so it is, that ymagis graued, coruun, or zut ben more lijk to Crist and to his passioun, than ben the sacramentis whiche Crist ordeyned; .... Wherfore folewith, sithin bi Holi Scripture it is leeful and expedient forto haue and vse the seable sacramentis, whiche Crist made as seable ymagis of Crist and of his passioun and deeth, it is ther yn impliedli bi Holi Scripture leeful and expedient for to haue seable ymagis graued, coruun, and zut of Cristis persoon, figurid lijk to his persoon, with purtenauncis of his passioun and deeth, forto make us remembre upon him and his passioun and deeth. ${ }^{104}$

By this logic a painting is apparently more like Christ than the eucharistic wafer, and the three-dimensional sculpture is more like Christ than a painting. By extension, an image capable of movement would be more like Christ than an image unable to move and would therefore be a more effective 'rememorative' sign. ${ }^{105}$ The mechanical image was not necessarily an object designed to trick or confuse.

In 'Iconoclasm in England: Official and Clandestine', Margaret Aston warns that 'not all illusions were to be equated with delusion. Those who watched a Resurrection play, or a carved Christ being elevated from an Easter Sepulchre on Easter Day, could both revere the miraculous and respect the limitations of physical enactment'. But the reformers' response to ritual and imagery was in general less complex. Aston writes, 'representation itself became different for those who tended to see the suspension of disbelief as akin to submission to misbelief" 106

Earlier in the same article Aston notes the 'selfconscious theatricality of the occasion' of the 'exposure' and destruction of the Rood of Boxley described in Finch's letter, and in many of the other texts described above. She suggests that this (overt and exaggerated) theatricality was 'obviously framed to impress the "simple people", 107 the implication being that theatricality and spectacle, it was assumed, could effectively persuade the ignorant and silly. This assumption fit with developing (and increasingly cultivated) representations of and prejudices against both pilgrims and the audiences of puppet theatre.

We can push this reading still further. I suspect that the strategy of parading the Rood on a scaffold (or at very least of representing the Rood as having been paraded on a scaffold), on something like a stage for human or puppet actors, was intended to extricate the image from its complex representational/ 
ritual context (in which theatre and miracle might coincide) to place it into a strictly representational context, making the task of reading it less difficult as well as less individual and affective. This project might have involved as well the task of establishing clearer categories and contexts. With the mediating influence of parish priests and the various spiritual religious, Catholicism developed complex systems of signification and readings/responses. With the translation of the scriptures, their insisted-upon clarity, and the imperative to uniformity of interpretation and belief, based on scripture's literal meaning, simplicity became a necessity.

The Rood moved out from the abbey church into the market place, exposed as puppet theatre when prised from the wall by reformers and 'discovered' to have within it 'certen ingynes and olde wyer, wyth olde roton stykkes'. ${ }^{108}$ In the marketplace, a new puppeteer manipulated the Rood, one concerned not to produce a kind of miracle in his audience but instead to elicit the kind of laughter and titillation inspired by English glove puppets and, later, by the marvelous new marionettes arriving from the continent. The crowds witnessing the destruction of the Rood were not only appealed to (and represented) as the ignorant and simple spectators who flocked to puppet plays, but were also appealed to (and represented) as nothing like those naïve and rude spectators, from whom they were encouraged to dissociate themselves.

\section{Notes}

An early version of this paper was presented at the 39th International Congress on Medieval Studies at the University of Western Michigan in Kalamazoo on 6 May 2004. I would like to thank the other presenters at this session and the members of the audience for their helpful comments. Special thanks as well to Garrett Epp for his advice on the topic of 'budgets' in William Grey's 'The Fantasie of Idolatrie'.

Philip Butterworth, Magic on the Early English Stage (Cambridge, 2005), 113.

Ibid, 123-4.

3 Ibid, 113.

4 Ibid, 126.

5 J. Brownbill, 'Boxley Abbey and the Rood of Grace', The Antiquary 7 (1883), 162-5, 210-13 (in two parts).

6 T.E. Bridgett, 'The Rood of Boxley; or, How a Lie Grows', The Dublin Review, 3rd ser, 19.1 (January 1888), 1-33. 
7 See Margaret Aston, 'Iconoclasm in England: Official and Clandestine', especially 56-61, and Clifford Davidson, “The Devil's Guts": Allegations of Superstition and Fraud in Religious Drama and Art during the Reformation', especially 95-7, in Iconoclasm vs. Art and Drama, Clifford Davidson and Ann Eljenholm Nichols (eds), vol 11, Early Drama, Art, and Music Monograph Series (Kalamazoo, 1989); see also Peter Marshall, 'The Rood of Boxley, the Blood of Hailes, and the Defence of the Henrician Church', The Journal of Ecclesiastical History, 46.4 (October 1995), 689-96, and 'Forgery and Miracles in the Reign of Henry VIII', Past \& Present, 178 (February 2003), 39-73.

8 Marshall, 'The Rood of Boxley', 691, n.10.

9 Bridgett, 'The Rood of Boxley', 8.

10 Ibid, 30 .

11 Ibid, 29.

12 In Original Letters Illustrative of English History, Henry Ellis (ed) (London, 1846; rpt New York, 1970), 3rd ser, vol 3, 168.

13 Chamber, Original Letters Illustrative, 168.

14 Charles Wriothesley, A Chronicle of England during the Reigns of the Tudors, William Douglas Hamilton (ed) (London, 1875; rpt New York, 1965), vol 1, 74.

15 London Chronicle during the Reigns of Henry the Seventh and Henry the Eighth, Clarence Hopper (ed), in Camden Miscellany, vol 4, no 1 (London, 1859; rpt New York: AMS Press, 1968), 11-12.

16 In Original Letters Relative to the English Reformation, Hastings Robinson (ed), for The Parker Society (Cambridge, 1847; rpt New York, 1968), 606-7.

17 In Original Letters Relative, 609.

18 Gilbert Burnet, History of the Reformation of the Church of England (London, 1825), vol 3, pt 2, 152-3.

19 Bridgett, 'The Rood of Boxley', 19.

20 James Gairdner also provides a translation of Hoker's letter in Lollardy and the Reformation in England (London, 1908; rpt New York, nd), vol 2, 124-6.

21 Bridgett, 'The Rood of Boxley', 19. 'Repertus est nuper Cantianorum Deus ligneus, pensilis Christus, vui cum ipso Protheo concertare potuisset. Nam et capite nutare, innuere oculis, barbam convertere, in curvare corpus, adeuntium aversari et recipere preces scitissimè noverat.' Burnet, History of the Reformation, vol 3, pt 2, 152.

22 Marshall, 'The Rood of Boxley', 694.

23 Public Record Office, SP 1/143, fo. 203. Quoted in Marshall (with ellipses), 694.

24 William Thomas, The Pilgrim: A Dialogue on the Life and Actions of King Henry the Eighth, ed. J.A. Froude (London, 1861), 4.

25 Thomas, Pilgrim, 37-38; quoted in Bridgett, 'The Rood of Boxley', 24-5. 
26 Bridgett, 'The Rood of Boxley', 25.

27 Gairdner, Lollardy, vol 2, 173.

28 William Grey, 'The Fantasie of Idolatrie', in John Foxe, Actes and monuments of these latter and perillous dayes touching matters of the Church, wherein ar comprehended and decribed the great persecutions [and] horrible troubles, that haue bene wrought and practised by the Romishe prelates, speciallye in this realme of England and Scotlande, from the yeare of our Lorde a thousande, vnto the tyme nowe present. Gathered and collected according to the true copies [and] wrytinges certificatorie, as wel of the parties them selues that suffered, as also out of the bishops registers, which wer the doers therof (London, 1563; STC 2nd ed: 11222), 590 (corrected pagination 603).

29 James Calfhill, An Answer to John Martiall's Treatise of the Cross, Richard Gibbings (ed), for The Parker Society (Cambridge, 1846; rpt, New York, 1968), 274.

30 William Lambarde, A Perambulation of Kent (London, 1576; STC 2nd ed: 15175), 182.

31 Ibid, 183.

32 Reginald Pecock, The Repressor of Over Much Blaming of the Clergy, Churchill Babington (ed) (London, 1860; rpt Wiesbaden, 1966), vol 1, 187.

33 George Speaight, The History of the English Puppet Theatre, 2nd ed (Carbondale, 1990), 66. Speaight's references are to The Silent Woman 3.2.; William Sampson, The Vow Breaker, or the Fair Maid of Clifton, act 5.

34 Butterworth, Magic, 126.

35 Gairdner in Lollardy and the Reformation in England describes Hoker's letter as 'a very artistic presentation of the matter', vol 2, 126.

36 Trans by Gorham in Reformation Gleanings, quoted in Bridgett, 'The Rood of Boxley', 20. 'Patefactus Meydstanuensibus meis spectaculum primitus dedit, ex summo se culmine confertissimo se ostentans populo, aliis ex animo, aliis Ajacem risu simulantibus. Delatus hinc circulator Londinum est. Invisit Aulam Regis, Regem ipsum, novus hospes: nemo salutat verè. Conglomerant ipsum risu aulico, Barones, Duces, Marchiones, Comites. Adsunt è longinquo, circumstand', intuend' et vidend' penitus. Agit ille, minatur oculis, aversatur ore, distorquet nares, mittit deorsum caput, incurvat dorsum, annuit et renuit. Vident, rident, mirantur, strepit vocibus theatrum, volitat super aethera clamor. ... Hic denuo sese aperis, hic denuò coram fabulam scitè agit'. Burnet, History of the Reformation, vol 3, pt 2, 152.

37 Translated by Gorham in Reformation Gleanings, quoted in Bridgett, 'The Rood of Boxley', 20.

38 Burnet, History of the Reformation, vol 3, pt 2, 152.

39 Speaight, History of English Puppet Theatre, 54.

40 Ibid, 65-6. 
41 Ibid, 53.

42 Ibid, 31.

43 See for example Speaight, History of English Puppet Theatre, 35-43; Henryk Jurkowski, A History of European Puppetry, from its Origins to the End of the 19th Century, Penny Francis (ed) (Lewiston/Queenston/Lampeter, 1996), vol 1, 98-9; Max von Boehn, Puppets and Automata, Josephine Nicoll (trans) (1929; New York, 1972), 56-64.

44 Speaight, History of English Puppet Theatre, 36.

46 Ibid, 55.

46 Ibid, 55-6.

47 Butterworth, Magic, 138.

48 Thomas, Pilgrim, 38.

49 Lambarde, Perambulation (1576), 186.

50 Ibid, 187-8.

51 This obsession with revising and updating his works is evinced as well in his 1596 edition of the Perambulation. Lambarde revisited the above passage yet again, making the reference still more current. The emended passage reads as follows: 'the poore Pilgrimes could not assure themselves of any good, gained by all their labour. No more than such as goe to Parisgardein, the Bell Savage, or Theatre, to beholde Beare baiting, Enterludes, or Fence play can account of any pleasant spectacle '(London, 1596; London, 1826), 210-11. James Burbage's Theatre was no longer new in 1596, but perhaps was added to represent the newer Shoreditch theatre district as well as Bankside (Paris Garden) and the city proper (the Bell Savage).

52 Speaight, History of English Puppet Theatre, 61-2.

53 The Second Tome of Homilies, of suche matters as were promised, and intituled in the former part of Homilies (1577), title page.

54 Lactantius, book two, chapter four, Divine Institutes, Mary Francis McDonald (trans), vol 49, The Fathers of the Church (Washington, 1964), 107.

55 Second Tome of Homilies, 151.

56 Second Tome of Homilies, 152-3.

57 Scott Cutler Shershow, Puppets and 'Popular' Culture (Ithaca and London, 1995), 23.

58 Shershow, 24.

59 Second Tome of Homilies, 133, 134. Images then are no better than prostitutes, while those who use them are no better than'folc of avoutrie', as the much earlier Tretise of Miraclis Pleyinge calls their equivalent (the audiences of miracle plays). These 'folc' 'siche singnys as a lecchour sechith signes of verrey love but no dedis of verrey love'. Images, puppets, plays 'ben onely singnis, love withoute dedis' and therefore are 'not 
onely contrarious to the worschipe of God — that is, bothe in signe and in dede—but also they ben ginnys of the devvel to cacchen men to byleve of Anticrist, as wordis of love withoute verrey dede ben ginnys of the lecchour to cacchen felawchipe to fulfillinge of his leccherie'. A Tretise of Miraclis Pleyinge, Clifford Davidson (ed), vol 19, Early Drama, Art, and Music Monograph Series (Kalamazoo, 1993), 99, 11 200-6.

60 See Shershow, Puppets and 'Popular' Culture, 68-72.

61 Second Tome of Homilies, 152.

62 'Veneri donatae a uirgine pupae.' A. Persi Flacci et D. Iuni Iuvenalis saturae (Oxford, 1959), 11, 170.

63 Lactantius, Divine Institutes, 107; quoted in Shershow, Puppets and 'Popular' Culture, 25.

64 Shershow, Puppets and 'Popular' Culture, 25-6.

65 Lambarde, Perambulation (1576), 187.

66 Ibid, 187.

67 Ibid, 185.

68 Many puppets plays seem to have been quite sexual but not all. Evidence survives of puppet plays on religious subjects—-see for example Margaret Rogerson's 'English Puppets and the Survival of Religious Theatre', Theatre Notebook 52.2 (1998), 91-111.

69 Ian Lancashire, “'Ioly Walte and Malkyng”: a Grimsby puppet play in 1431', REED Newsletter 2 (1979), 6.

70 Ibid, 7.

71 Henry Chettle and John Day, The Blind-Beggar of Bednal-Green (London: 1659); act 4, G2r. Quoted in Jurkowski, History of European Puppetry, vol 1, 82, and in Shershow, Puppets and 'Popular' Culture, 47.

72 Lording Barry, Ram-Alley or Merrie-Tricks, The Tudor Facsimile Texts (London: 1611; London: 1913; New York, 1970), E4r.

73 Speaight, History of the English Puppet Theatre, 65.

74 Quotations are taken from Ben Jonson, Bartholmew Fair, G.R. Hibbard (ed), The New Mermaids (New York: 1977).

75 Grey, 'The Fantasie of Idolatrie', 590 (corrected pagination 603).

76 Ibid, 590 (corrected pagination 603).

77 Ibid, 589 (corrected pagination 604).

78 The ballad cannot be read for historical information about the Rood of Boxley, but it is possible that the crucifix actually had a coat as evidence survives of garments used to 'dress' crucifixes for liturgical use after Easter Sunday and the Resurrection. See Bridgett, 'The Rood of Boxley', 8. 
79 Butterworth in Magic on the Early English Stage describes this type of purse or bag and its use: 'Jugglers frequently carried a bag that was fastened around the waist. Such bags could be left open or closed by a flap. These bags contained the accoutrements of the juggler and were also a means of enabling items to disappear. Terms used to describe such bags were the purse, the budget and the gibecière or gipser' (87).

80 As argued by Leo Steinberg in The Sexuality of Christ in Renaissance Art and in Modern Oblivion (Chicago, 1983, revised and expanded 1996).

81 Grey, 'The Fantasie of Idolatrie', 589 (corrected pagination 604).

82 Shershow, Puppets and 'Popular' Culture, 57.

83 Expansions in original. David George, 'Anti-Catholic Plays, Puppet Shows, and Horse-Racing in Reformation Lancashire', REED Newsletter, 19.1 (1994), 17.

84 In Original Letters Relative, 607.

85 Thomas, The Pilgrim, 40, 41-2, 43.

86 Grey, 'The Fantasie of Idolatrie', 590 (corrected pagination 603).

87 Ibid, 589 (corrected pagination 604).

88 See also Butterworth who discusses the nature of juggling generally and its representation by those who believed themselves immune to such deception:

It is relatively easy to label responses as naïve when the witness or audience does not share in or is not party to the juggling intention. A number of accounts refer to the juggling audience as 'simple people' and they do so with an apparent sense of superiority that arises out of knowledge of the deception. This is not necessarily knowledge of the means of deception; it is simply knowledge of the fact that the deception takes place. Take for instance the comments made by William Lambard [sic] in his A Perambulation of Kent (1576) where he refers to those people who were deceived by the Rood of Boxley as 'the sillie lambes of Gods flocke'. Johh Gee, in his The Foot out of the Snare (1624), compares acts of the Catholic Church with those of 'puppets, apes-faces and gawds' through 'allures, masks, and disguises' and recipients of them as 'the poor silly people'. (Magic, 155)

89 Grey, 'The Fantasie of Idolatrie', 590 (corrected pagination 603).

90 Second Tome of Homilies, 116.

91 In Original Letters Relative, 606.

92 London Chronicle, Hopper (ed), 14.

93 Wriothesley, A Chronicle, vol 1, 74.

94 Lambarde, Perambulation (1576), 185.

95 'From a loose paper in Mr. Ashmole's handwriting, 26th August, 1668', in The Antiquarian Repertory, ed. Francis Gross, III (1808), 349-50. Quoted in 'More on Medieval Puppets', The EDAM Newsletter, 10.2 (March 1988), 33. 
96 John Foxe, The first volume of the ecclesiasticall history contaynyng the actes and monumentes of thynges passed in euery kynges tyme in this realme, especially in the Church of England principally to be noted: with a full discourse of such persecutions, horrible troubles, the sufferyng of martyrs, and other thinges incident, touchyng aswel the sayd Church of England as also Scotland, and all other foreine nations, from the primitiue tyme till the reigne of K. Henry VIII (London, 1570; STC second edition: 11223), 1359. Also quoted in Bridgett, 'The Rood of Boxley', 23.

97 Lambarde, Perambulation (1576), 182.

98 Ibid, 184-5.

99 Ibid, 182.

100 Bridgett, 'The Rood of Boxley', 14.

101 Brownbill, 'Boxley Abbey', 212.

102 Verdi Webster, Art and Ritual in Golden-Age Spain: Sevillian Confraternities and the Processional Sculpture of Holy Week (Princeton, 1998), 3-4.

103 Pecock, Repressor, vol 1, 136-7.

104 Pecock, Repressor, vol 1, 163, 164.

105 The only more effective sign of Christ's passion would be 'a quyk man ... sett in a pley to be hangid nakid on a cros and ... in semyng woundid and scourgid'. Yet, Pecock notes, 'this bifallith ful seelde and in fewe placis and cuntrees'(vol 1, 221).

106 Aston, 'Iconoclasm in England', 61.

107 Ibid, 57.

108 In Original Letters Illustrative, vol 3, 168. 